\title{
ON THE LOPHOZIA GROENLANDICA (NEES) MACOUN (HEPATICAE) O LOPHOZIA GROENLANDICA (NEES) MACOUN (HEPATICAE)
}

\author{
ROMAN N. SCHLJAKOV ${ }^{1}$ \\ РОМАН НИКОЛАЕВИЧ ШлЯКОВ ${ }^{1}$
}

Abstract

\begin{abstract}
Damsholt's (1994) conclusion on the identity of Lophozia grooenlandica (Nees) Macoun with L. wenzelii (Nees) Steph. is discussed. It is considered to be erroneous. Lophozia confertifolia Schiffn. is a synonym of L. groenlandica. Included also a discussion on the differences between L. groenlandica and L. ventricosa (Dicks.) Dum.
\end{abstract}

Резюме

Обсуждается заключение Дамшольта (Damsholt, 1994) об идентичности Lophozia grooenlandica (Nees) Macoun и L. wenzelii (Nees) Steph., и приводятся доводы о том, что оно ошибочно. Lophozia confertifolia Schiffn. отнесена в синонимы L. groenlandica. Рассматриваются также отличия между L. groenlandica и L. ventricosa (Dicks.) Dum.

Lophozia groenlandica (Nees) Macoun is a species, which was differently interpreted by hepaticologists. K. Müller (1954) and Schuster (1953) included it in L. wenzelii (Nees) Steph., but later Schuster (1969) found it to be a separate species, close to L. wenzelii. However, Schljakov (1975b) found that L. groenlandica sensu Schuster belongs to another species, L. schusterana Schljak. Recently Damsholt (1994) has typifyed Jungermannia groenlandica Nees and concluded that the lectotype belong to $L$. wenzelii. Though I agree with Damsholt's lectotypification, the arguments that it is L. wenzelii seems to me erroneous.

My contrarguments are as follow. Nees described Jungermannia groenlandica with leaves bi- or trilobed, lobes unequal, ventral margin of leaf strongly arched (in Lophozia wenzelii both margins are arched, cf. Schuster, 1969). The illustrations in Flora Danica (Steenstrup \& Lange, 1858, tab. 2626), which has been reproduced by Damsholt (1994), do not confirm the close relation of Jungermannia groenlandica to Lophozia wenzelii, since in the former species leaves are widest below the middle and have angular sinus (in L. wenzelii - semilunate); also the shape of lobes (fig. 2626g) is different - their margins are convex (arched) on both sides, not only on one as in L. wenzelii.
Damsholt stated that Lophozia groenlandica does not belong to the sect. Heteromorphae Schust. because in this species there are no underleaves and leaves are non-polymorphous and bilobed (not 2-3(-4)-lobed). However, the revision of characters of sect. Heteromorphae (Schljakov, 1980) demonstrated that these characters are not of great taxonomic importance in this case, while the most important are: (1) broad ventral segment of stem, and this segment causes the occasional occurrence of underleaves in some populations of $L$. groenlandica; (2) direction of longitudinal cell rows in leaves, namely: median longitudinal rows follow to the sinus base from the middle of leaf base or, more often, closer to dorsal margin (Schljakov, 1974, 1980). At the same time in Lophozia wenzelii as well as the other species of the sect. Lophozia cell rows follow from base into lobes and its leaves are widest mainly at the middle or slightly above (in L. groenlandica leaves are widest below the middle). Differences of L. groenlandica and L. wenzelii are summarized in Table 1.

Lophozia groenlandica is a polymorphic species. In exposed sites occur phases with concave leaves, very often reddish, vinaceous or purplish; plants from swamps are loosely leaved, sometimes with trilobed leaves (heteromorpha-

\footnotetext{
1 - Россия 197376 Санкт-Петербург, проф. Попова, 2, Ботанический институт им. В. Л. Комарова PAH - V. L. Komarov Botanical Institute of the Russian Academy of Sciences, 2 Prof. Popov str., St.-Petersburg 197376, Russia
} 


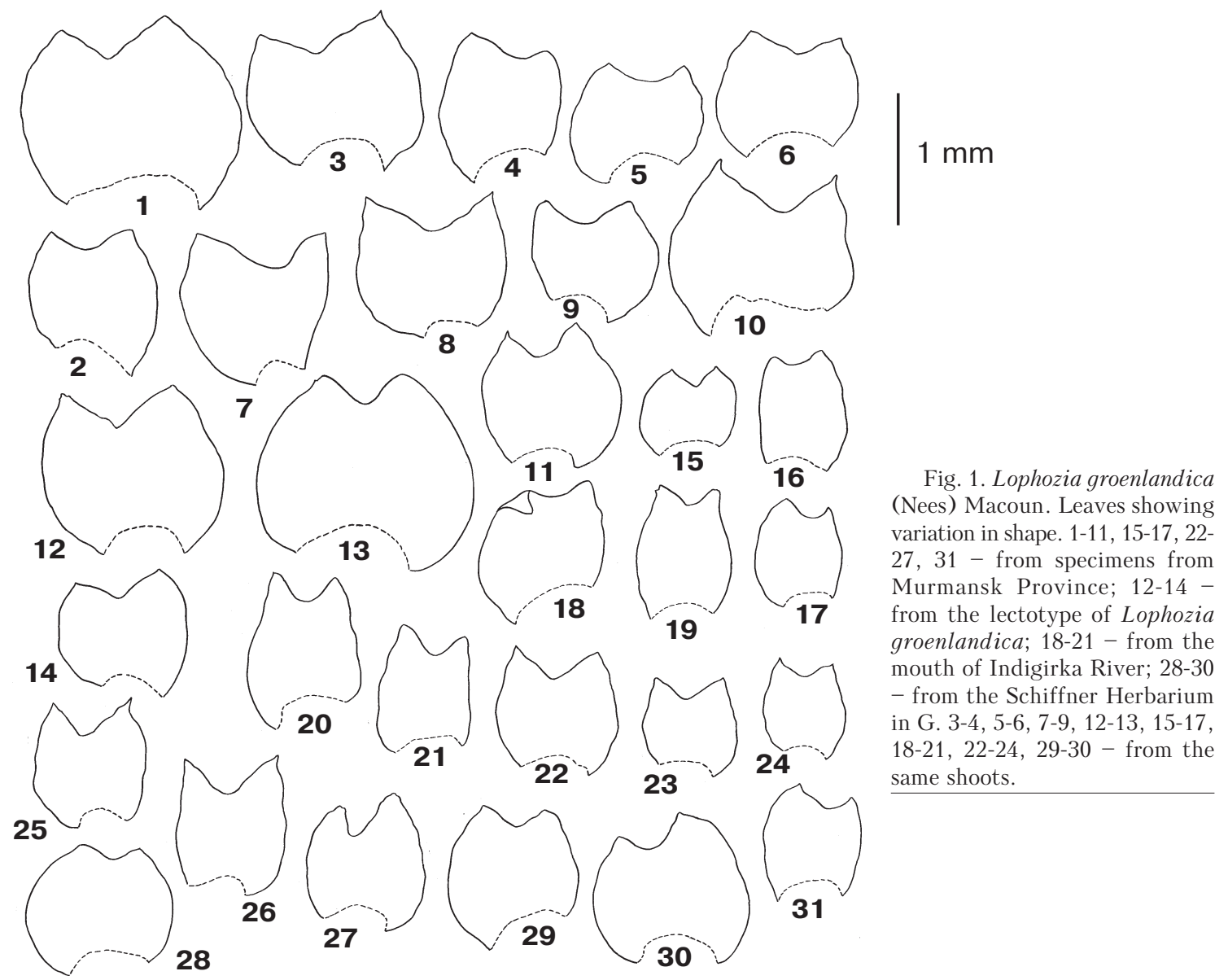

like phase, Figs. 1, 2). In forests and humid (but not swampy) woodless sites the most frequent is Lophozia ventricosa-like phase, differing from L. ventricosa in oil-bodies uniformly granular, while in the latter oil-bodies are biconcentric, with distinctly refractive central globule. I agree with the K. Müller's (1954) conception of oil bodies of Lophozia ventricosa against the al-

Table 1. Differences between Lophozia groenlandica (Nees) Macoun and L. wenzelii (Nees) Steph.

\section{Character}

Leaf shape

Sinus

Leaf margin

Direction of the longitudinal cell rows in leaves

Underleaves or under- Sometimes present (Figs 2, 4; 3,4) leaf-like structures

\section{Lophozia groenlandica}

Asymmetric, with larger ventral lobe, widest near or slightly below the middle Nearly rectangular, wide acutangular or obtusangular with rounded base, $1 / 6$ to $2 / 5(1 / 2$ and more $)$ of leaf length

Ventral strongly arched, with postical part (postical leaf base) distinctly turned down (Fig. 1)

From the middle of leaf base at least in 2-3 cell rows to the sinus (Fig. 2, 5)

\section{Lophozia wenzelii}

Nearly symmetric, widest near or above the middle

"Broad (width ca. 0.5-0.66 leaf width; ca. 0.7-0.9 leaf length), shallowly crescentic, descending only to 0.15-0.2(0.25)"(Schuster, 1969)

Both margins nearly equally arched, postical leaf base hardly curved

From the middle of the base into lobes (Schljakov, 1980, Fig. 23, 4)

Absent 

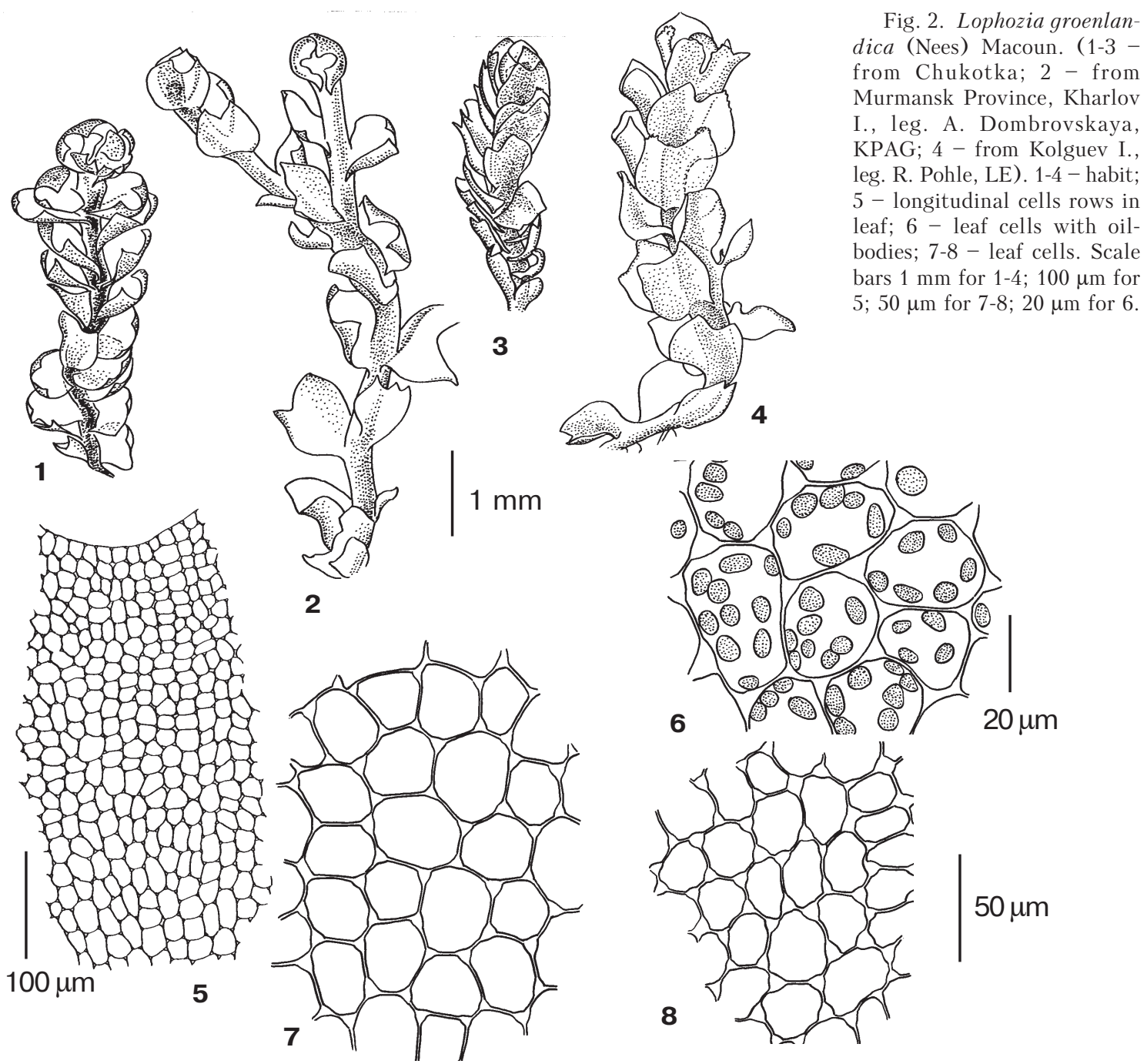

ternative interpretation of Buch (1933b). Buch has described L. silvicola Buch as a new species, which differs from $L$. ventricosa in biconcentric (not uniformly granular) oil-bodies. However Müller (1.c.: 649) came to the conclusion that L. silvicola is just the real L. ventricosa. He stated that specimens of $L$. ventricosa sent to him by Buch belong to a different species and that Buch agreed with him in this point. So the conception of Buch (1933b), repeated by Saukel (1985) and Schuster (1969) can not be accepted.

Jungermannia ventricosa Dicks. was described from woods of Britain ("Brittania, in sylvis"). However among the specimens named $L$. ventricosa from the Great Britain in BM, plants with the characters of Buch's "L. ven- tricosa" were collected mostly in non-forest habitats.

Once in the South-Western part of Murmansk Province I have found the mixed collection of $L$. groenlandica and $L$. ventricosa. The comparison of plants from this collection is given in Table 2. Many other observations of living collection in Murmansk Province just confirm the stability of combinations of characters of these species.

The shape of leaves of Lophozia groenlandica is not constant (Fig. 1). Leaves are widest usually below or at the middle, but some are widest above (Fig. 1, 7-8). Lobes are either obtuse, or acutish to shortly pointed. Although as a rule leaves are broader than long, occasionally plants with narrower leaves occur. In 


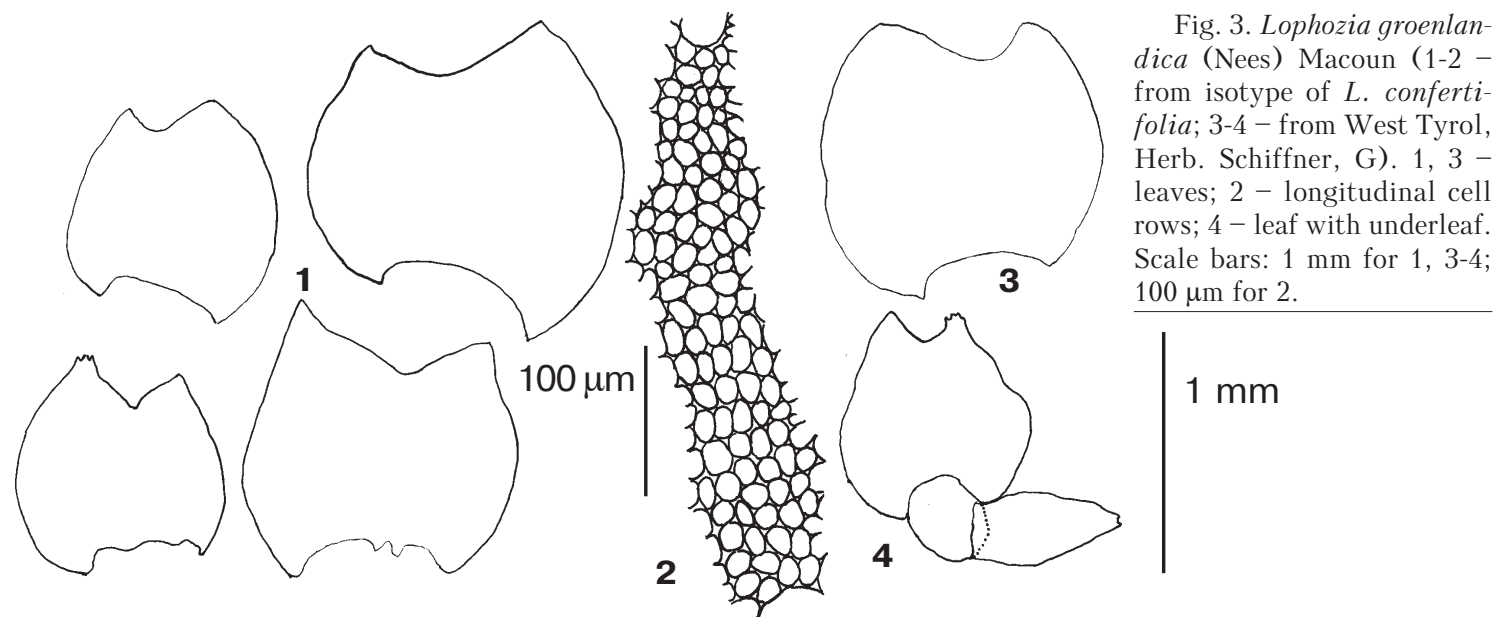

specimens from the dry polygonal Arctic bog of the delta of Indigirka River in Yakutia I found upper leaves normal for the species (cf. Fig. 1, 18), while lower leaves are narrower (Fig. 1, 19-21). Areolation is variable and the following patterns can be recognized: mod. leptoderma, nearly without trigones; mod. mesoderma, with clear but not bulging trigones (Fig. $2,6)$ and mod. pachyderma, with bulging trigones (Fig. 2, 7).

Another problematical species presenting a point of disaggrements among hepaticologists is L. confertifolia Schiffn. Buch (1933b), Müller (1954) and Saukel (1985) interpreted it to be conspecific with $L$. wenzelii, and Schuster (1969) considered it as "a concept (rather than a species) that appears to involve the mod. densifolia of both L. ventricosa and L. wenzelii". I found the isotype of this species identical with $L$. groenlandica: it has leaves as a rule widest at or slightly below the middle; with larger ventral lobe, having strongly arched ventral margin, proximal part of which (postical leaf base) distinctly turned down (Fig. 3, 1); the direction of cell rows in leaf is similar to that of L. groenlandica, from base to sinus (Fig. 3, 2).

Saukel (1985) wrote that Buch (1933a) has proved identity of $L$. confertifolia and $L$. wenzelii experimentally. However, Buch made this conclusion only on the basis of habits of $L$. confertifolia and L. wenzelii mod. densifolia. Therefore this is not a very good argument.

Table 2. Differences between Lophozia groenlandica (Nees) Macoun and L. ventricosa (Dicks.) Dum., from plants of mixed collection

Character

Oil-bodies

Direction of the longitudinal cell rows in leaves

Leaf shape

Postical base

Postical end of the insertion line

Coloration in pigmented leaves Gemmae

\section{Lophozia ventricosa}

Biconcentric

From the middle of leaf base into lobes (see Schljakov, 1980, Fig. 23, 3)

Equal or longer than broad

Hardly curved

Scarcely curved backward

Proximal part colorated distal colorless

Usually subsquare and polygonal

\section{Lophozia groenlandica}

Homogeneous, uniformly minutely granular From the middle of leaf base in (1-)2-3 rows to the sinus base

Shorter than broad

Distinctly turned down

Weakly but appreciably arched

Distal part colorated, downward gradually colorless

Usually rounded- and elongate-triangular and polygonal (Schljakov, 1970, Fig. 2, 9); abundand when present 
The synonymy of Lophozia groenlandica is as follow:

Lophozia groenlandica (Nees) Macoun, Cat. Canad. Pl. 7: 19. 1902.- Jungermannia groenlandica Nees in Gott. et al., Syn. Hep.: 114. 1844. Lectotype: S. Groenland, Frederiksdal (Narksak). Leg. J. Vahl, Sept. 1829 No 234 "a” (STR!)

Lophozia confertifolia Schiffn., Oesterr. Bot. Zeitschr. 55: 47. 1905. Isотype: V. Schiffner: Hepaticae europaeae exiccatae, 176. Tyrol, Am Glungezer bei Hall, oberhalb der Schafhuette auf alpinem Humus und auf erdbedeckten Steinen, 230 m, 4.IX.1903, leg. V. Schiffner et H. F. V. Handel-Mazzetti (H!).

Lophozia ventricosa auct. pl., non (Dicks.) Dum.; Buch, Ann. Bryol. 6: 127. 1933.

(?)Lophozia murmanica Kaal. in Bryhn, Rep. 2nd Norw. Arct. exped. "Fram" 2, 11(1): 34. 1906. Type: Lapponiae murmanicae, Litsa, leg. Brotherus, August 1887 (not seen) ${ }^{1}$.

(?)Lophozia heteromorpha Schust. et Damsch. in Schust., Hep. Anthoc. North Amer. 2: 507. 1969. TyPE: Northwest Greenland, Hackluyt I. in Smith Sound, $77^{\circ} 24^{\prime} \mathrm{N}-72^{\circ} 31^{\prime} \mathrm{W}$. G. Seidedfaden 85 (not seen) ${ }^{2}$.

Lophozia groenlandica is a widespread circumpolar species, known from the high Arctic southwards to the hemiboreal zone, and in mountain region of the temperate latitude, including Alps. It is the most common species of the genus Lophozia s. str. in Ural and Altai Mts. It is frequent in South Finland (among 15 specimens identified by Buch as L. ventricosa and 10 - as L. silvicola, 8 and 5 correspondingly belong to $L$. groenlandica). It is likely that wide distribution of Lophozia groenlandica in Finland caused the Buch's misunderstanding of this material. In comparison with $L$. ventri$\cos a$, L. groenlandica has more northern distribution - the former species is rare in Arctic, but in Central Europe is widespread from plains to mountains, in Alps to $3000 \mathrm{~m}$ (Müller, 1954).

Selected specimens examined of L. groenlandica (from KPAG): FINLAND: Hepaticae exs.S. O. Lindberg (ed.by S. Piippo), 265, 266, 267 (all as L. ventricosa); CHECH REPUBLIC: Bryophyta Chechoslov. exs. 260 (as L. ventricosa); Sweden, Södermanland, Arnell 20.VII.1944 (as L. wenzelii).

Lophozia groenlandica occurs on rocks, on soil in dry and moist, sometimes swampy tundras and in forests on decaying wood and on tree roots. Lophozia ventricosa in northern parts of Kola Peninsula grows nearly exclusively on roots and decaying wood.

\section{AKNOWLEGEMENTS}

I'm very grateful to the curators of $\mathrm{H}$ and STR for specimens sent to me for study and to Dr. Anna V. Dombrovskaya for illustrations made by her to the paper. Also I'm thankful to L. T. Ellis for the loan of L. ventricosa specimens from BM.

\section{LITERATURE CITED}

BUCH, H. 1933a. Experimental-systmatische Untersuchungen über die Lophozia ventricosa-Gruppe. - Ann. Bryol. 6: 7-14.

BUCH, H. 1933b. Lophozia silvicola Buch sp. nov. - Ann. Bryol. 6: 125-129.

DAMSHOLT, K. 1994. On the identity of Jungermannia groenlandica Nees. - J. Hattori Bot. Lab. 75: 173-178.

MÜLLER, K. 1954. Die Lebermoose Europas (L. Rabenhorst's Kryptogamen-Flora 3d ed., Bd. 6).

SAUKEL, J. 1985. Zum Merkmalbestand einiger mitteleuropaeiscger Arten der Lebermoosgattung Lophozia (Dum.) Dum. (Sektion Lophozia) - Stapfia 14: 149-185.
SCHIFFNER, V. 1905. Eine neue europaeische Art der Gattung Lophozia - Oesterr. Bot. Zeitschr. 55: 47-50.

[SCHLJAKOV, R. N.] ШЛЯКОВ, Р. Н. 1970. Новая секция рода Lophozia Dum. emend. Loeske. - [New section of the genus Lophozia Dum. emend. Loeske] Hовости сист. низи. pacm. [Novosti Sist. Nizsh. Rast.] 7: 324-333.

[SCHLJAKOV, R. N.] ШЛЯКОВ, Р. Н. 1973. Систематические заметки по семейству Lophoziaceae Cavers. [Taxonomic notes on the family Lophoziaceae Cavers] Новости сист. низи. pacm. [Novosti Sist. Nizsh. Rast.] 10: 287-302.

[SCHLJAKOV, R. N.] ШЛЯкОВ, P. H. 1974. Важнейшие систематические признаки рода Lopho-

\footnotetext{
1 - Although I have not seen the type of L. murmanica, I have seen specimens from Kharlov I., the place very close to the type locality in Litsa, as well as numerous collections from many other places in Murmansk Province. They agree with the description of L.murmanica and fit my concept of L.groenlandica (cf. Fig. 1).

2 - Although I have not seen the type of L. heteromorpha, I have studied specimens kindly sent to me by Dr. K. Damsholt and found no characters which disagrees with L. groenlandica. The presence of underleaves I don't consider as a specific character, since in some collections with bilobed leaves I found underleaves (cf. Figs. 2, 4 and 3, 4).
} 
zia Dum. s. str. (листостебельные печеночники). [Significant taxonomic characters in the genus Lophozia s. str. (leafy Hepaticae)] Бот. Журн. [Bot. Zhurn.] 59(10): 1465-1471.

[SCHLJAKOV, R. N.] ШЛЯкОВ, P. H. 1975b. Дополнения к флоре печеночников Советской Арктики. - [Additions to the liverwort flora of the Soviet Arctic] Hовости сист. низи. pacm. [Novosti Sist. Nizsh. Rast.] 12: 318-323.

[SCHLJAKOV, R. N.] ШЛЯКОВ, P. H. 1980. Печеночные мхи Севера СССР. Вып. 3. Печеночники: лофозиевые, мезоптихиевые. - [Liverworts and hornworts of the North of the USSR. 3. Lophoziaceae - Mesoptychiaceae] Л., Наука [Leningrad, Nauka], 188.

SCHUSTER, R. M. 1953. Boreal Hepaticae, a manual of the liverworts of Minnesota and adjacent region. - Amer. Midl. Nat. 49(2): 257-684.

SCHUSTER, R. M. 1969. The Hepaticae and Anthocerotae of North America East of the hundredth meridian. 2. NY-London, Columbia Univ. Press XII+1062.

STEENSTRUP, J. \& J. LANGE 1858. Flora Danica 15 (44) Hauniae: 1-21 (tabs. 2581-2640). 